\title{
Natural stone deposits in an assemblage of subhorizontal intrusions - The Kuru granite batholith
}

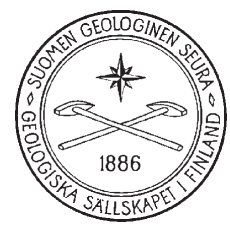

\author{
Olavi Selonen ${ }^{1)^{*}}$, Carl Ehlers ${ }^{1)}$, \\ PaAVO Härmä ${ }^{2)}$ and Rasmus Nyman ${ }^{1)}$ \\ 1) Ábo Akademi University, Department of Natural Sciences, \\ Geology and Mineralogy, FI-20500 Turku, Finland \\ 2) Geological Survey of Finland, FI-02151 Espoo, Finland
}

Keywords: granites, natural stonen, building stone, granite deposits, batholiths, intrusions, magmatism, Paleoproterozoic, Kuru, Finland

* Corresponding author e-mail: olavi.selonen@abo.fi

Editorial handling: Joonas Virtasalo

\section{Introduction}

The Kuru granite batholith is situated in the southern parts of the Central Finland Granitoid Complex (CFGC) (Fig. 1). The batholith is composed of intrusions ranging in composition from gabbros and diorites to red and grey granites (Fig. 1). The grey granite yields a U-Pb zircon age of $1875 \pm 5 \mathrm{Ma}$, indicating an age slightly younger than that of the average synkinematic granitoids of the CFGC (Nironen, 2003; Nironen, 2005). Tectonically, the area is characterized by prominent regional NW-SE and SW-NE trending lineaments (Selonen \& Ehlers, 1996; Nironen et al., 2000; Nironen, 2003).

The Kuru batholith is one of the traditional Finnish stone cutting regions. Industrial extraction and processing of grey granite started in the mid $19^{\text {th }}$ century for domestic use (building of the city of Tampere, approx. $50 \mathrm{~km}$ south of the batholith), and somewhat later for export (Aurola, 1967; Kylkilahti, 1989; Selonen \& Härmä, 2003). Today, the classical Kuru Grey is a regular product in the selection of Finnish granites with applications in the global market for facades, floors and interiors, and (especially in Japan) as a popular monument stone. Special products of this stone, requiring great soundness of the material, have included rolls for paper machines. Other stone varieties comprise the red granite Kuru Red Brown and the quartz diorite Kuru Black/Black Star, but they are produced in marginal quantities compared to the voluminously quarried Kuru Grey (Selonen \& Härmä, 2003).

Although being an important resource for natural stone, only few investigations have been published on the Kuru batholith. Except for the 


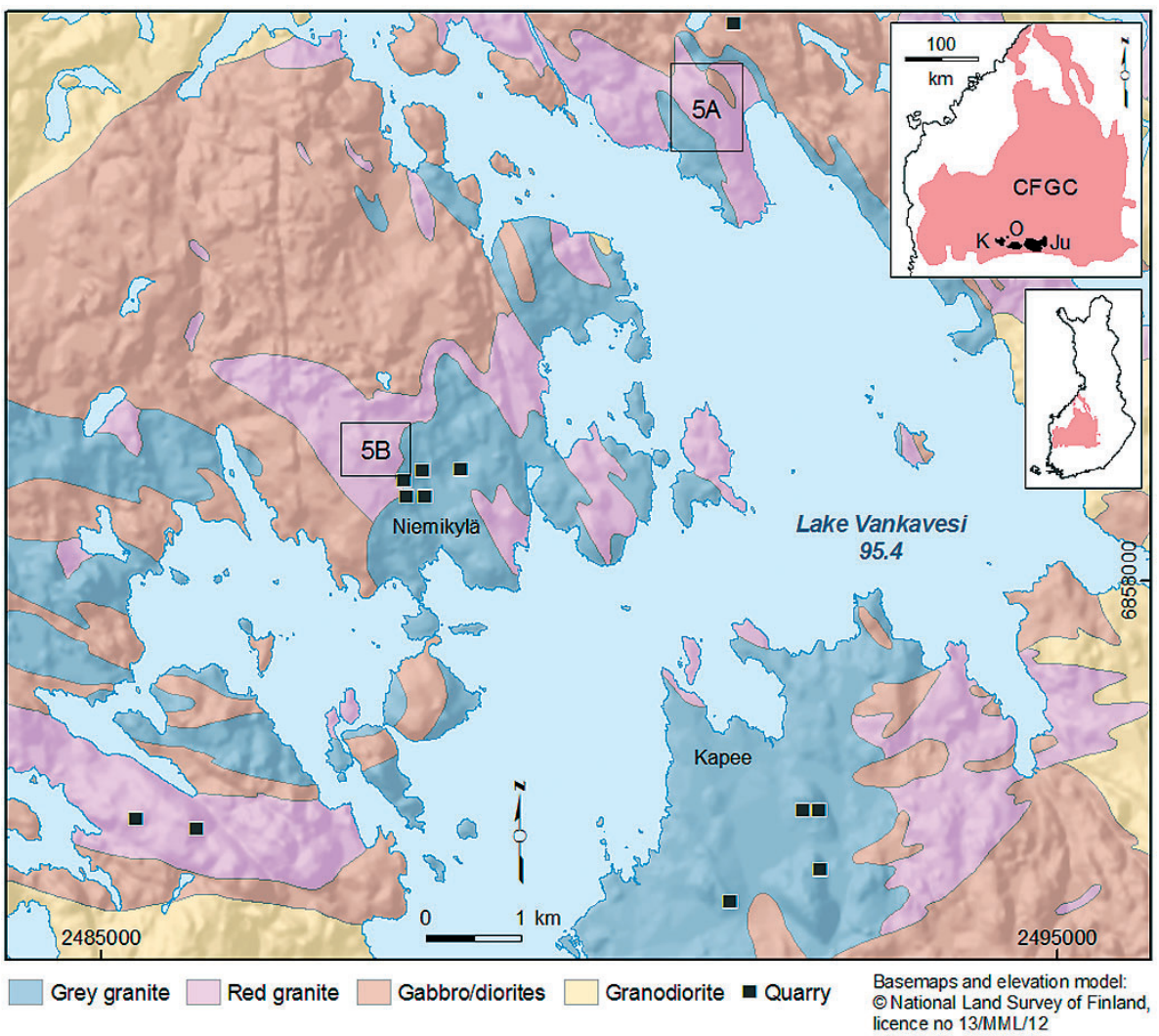

Fig. 1. Geological map of the Kuru district. The Kuru granite batholith is surrounded by granodiorite. The intrusions at the southern margin of the Central Finland Granitoid Complex (CFGC) in the inset are Kuru (K), Orivesi (O), and Juupajoki (Ju). Present quarries are shown on the map, see Aurola (1967) for historic locations. Modified from Aurola (1967) and Selonen \& Ehlers (1996). Locations of Figs. 5A and 5B are indicated with rectangles.

geological maps (Simonen, 1952; Matisto, 1961; Nironen, 2003), the only major published work is the paper by Aurola (1967).

We have carried out geological studies (Nyman, 2007) as well as prospecting for natural stone (Härmä et al., 2006) in the Kuru district. In 2011 selected parts of the area were revisited. In this paper we report the main rock types and their natural stone properties and discuss the geological constraints for the localization of the natural stone deposits in the Kuru batholith. We address the structure of the batholith as an assemblage of subhorizontal sheets of intrusion. The gently dipping structure has not been previously described, only briefly indicated by Aurola (1967). This article is part of our series of publications on the geological aspects in occurrence of natural stone (see, e.g. Selonen et al., 2011).

\section{Rock types and their natural stone properties}

\subsection{Grey granite}

The commercially most important rock type of the Kuru batholith, the grey granite, extends over an approx. $20 \mathrm{~km}^{2}$ large area in the centre of the batholith around Lake Vankavesi (Fig. 1). The colour of the granite is distinctively grey (Fig. 2A) with occasional variations towards green, blue, and red. A local red colouring occurs along pronounced vertical and horizontal fractures. The texture of the granite is generally homogenous and medium to fine-grained (Fig. 2A). A weak foliation and lineation (defined by biotite) can be occasionally observed. The average grain diameter is $0.3-2 \mathrm{~mm}$ 
(Aurola, 1967). Potassium feldspar, quartz, plagioclase $\left(\mathrm{An}_{20}\right)$ and biotite are the main minerals $(\mathrm{Ny}-$ man, 2007). The grey granite is microscopically very sound; only small micro cracks in quartz grains are reported (Nyman, 2007). Sparse coarse-grained enclaves and coarse-grained pegmatite veins are found in the grey granite. The granite shows the effects of magma mingling with more mafic rocks in several stages, indicating repeated influx of magma pulses.

The grey granite (Kuru Grey, Fig. 2A) is extracted from several quarries (Fig. 1). The granite is characterized by a very well-developed sheeting (Fig. $3 \mathrm{~A})$. The spacing of the sheeting joints varies between 0.2 and $4 \mathrm{~m}$ and is more intense close to the surface than deeper down. The vertical fractures are generally scarce with a spacing of 1-10 m.
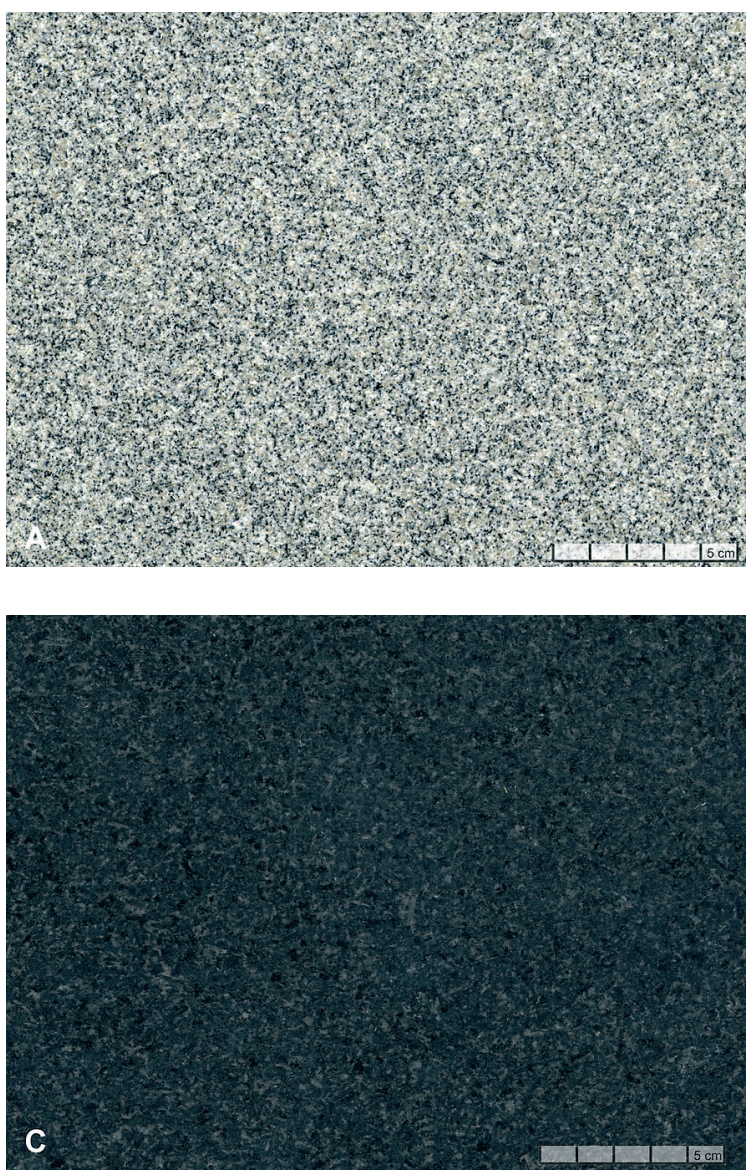

A typical feature at the grey granite quarries is the release of rock stress during quarrying, deforming the lowest parts of the horizontal sheets (Fig. 3B) and deforming drill holes. The maximum direction of the rock stress (as measured in the field) is approx. $110^{\circ}$, which is the general NW-SE direction found in Finland (Mononen, 2005). The deformation (and the rock stress) seems to increase with depth in the quarries.

Only a few future prospects in the grey granite have been identified. The area has been heavily exploited and most of the remaining potential locations are too close to settled areas. The main challenge in the quality of the granite is the local variations in appearance: colour variations (towards red) and darker schlieren-like structures ("flames"). The sparse fracturing would allow extraction in most areas.
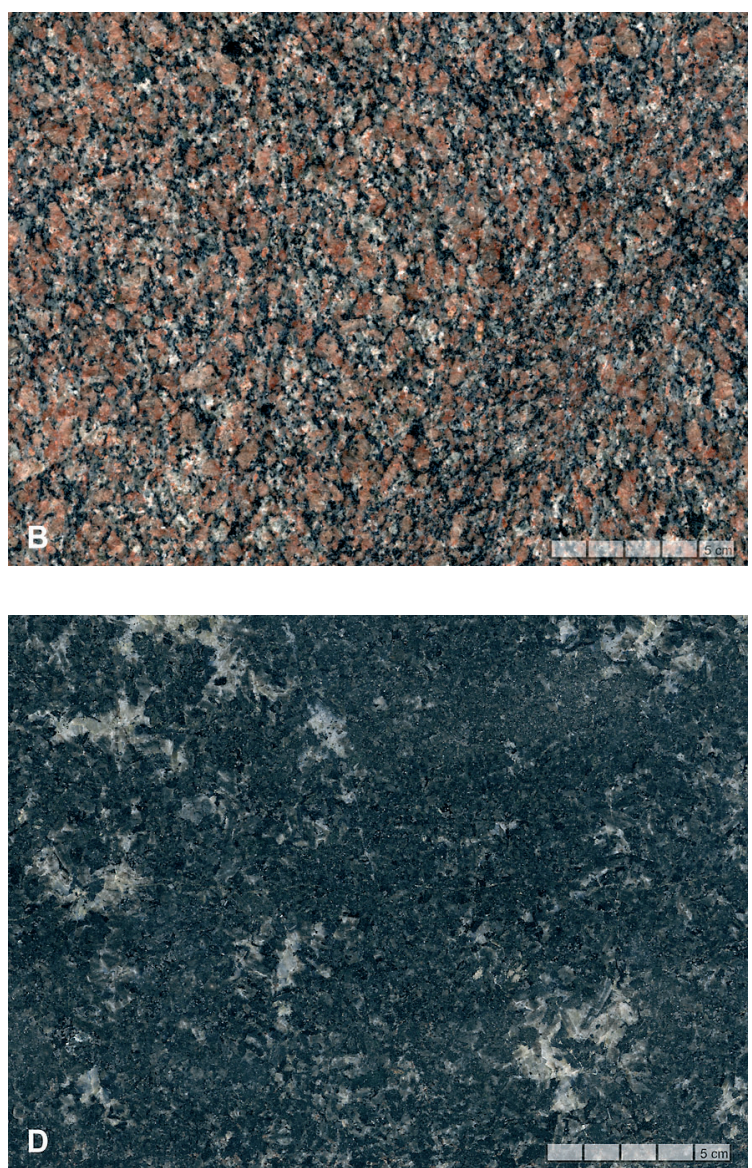

Fig. 2. Natural stones from the Kuru granite batholith. A. Kuru Grey, B. Kuru Redbrown, C. Kuru Black, D. Black Star. 

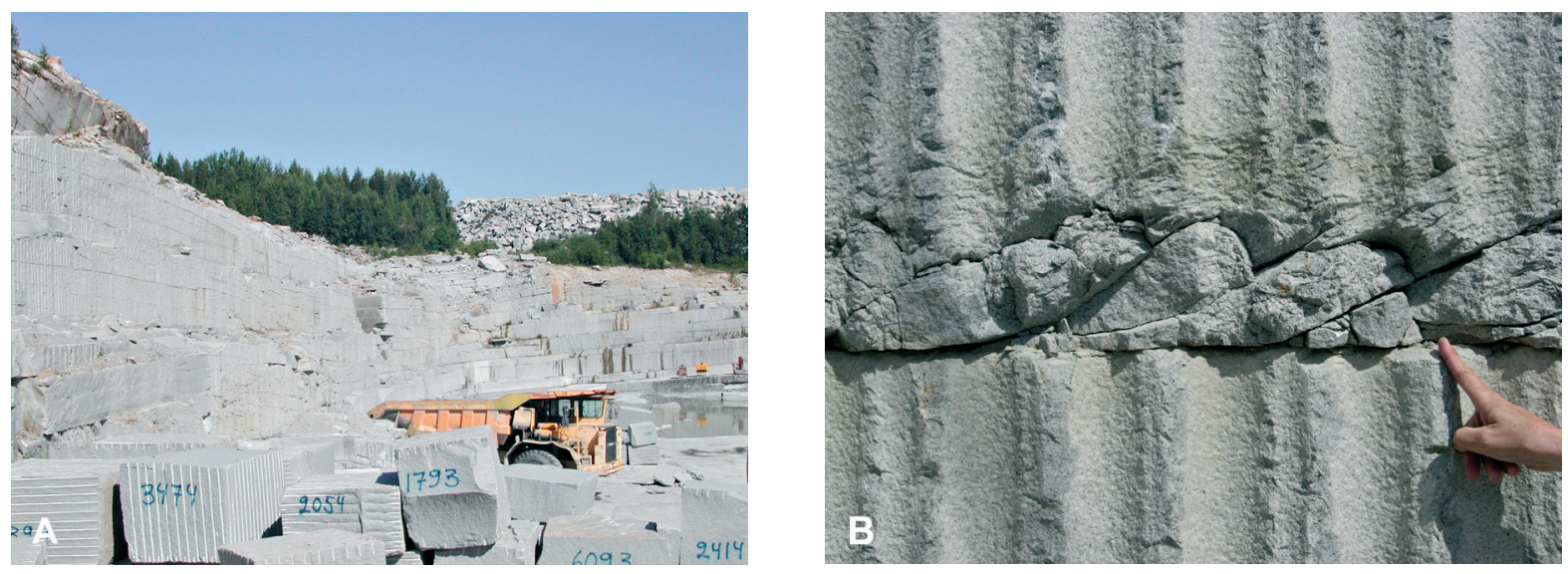

Fig. 3. A. Well-developed sheeting in the grey granite of the Kuru granite batholith. B. Deformation of the lower part of a horizontal sheet due to release of rock stress. Same quarry as in Fig. 3A. Vertical section in N-S direction. Finger as scale.

\subsection{Red granite}

The red granites show grain sizes varying from, medium even-grained to coarse-grained or porphyritic. They seem to occur as a relatively thin layer separating the grey granite from the overlying mafic rocks of the Kuru batholith (Fig. 1). The main minerals in the red granites are potassium feldspar, plagioclase, quartz and biotite (Nyman, 2007). Occasional pegmatite veins can be observed. Mingled mafic components, as rounded net-veined fragments and as flame-shaped schlieren are abundant in the red granites.

A red porphyritic, coarse-grained massive granite, sometimes with a weak foliation (defined by biotite), is the most important red stone quarried (Kuru Redbrown, Fig. 2B). It has a deep red brown colour, containing bluish quartz grains and potassium feldspar phenocrysts $(0.5-2 \mathrm{~cm}$ in size). The horizontal fracturing is poorly developed with a spacing of $0.1-2 \mathrm{~m}$; the vertical fractures are nonsystematic with a spacing of $0.5-4 \mathrm{~m}$. No orthogonal or wedge-like system of the vertical fracturing is observed.

A few additional future prospects in the red granites have been located (Härmä et al., 2006). The non-systematic horizontal fracturing and the variations in the appearance with a multitude of mafic inclusions pose challenges for exploitation.
Intensely red brown rock types are commercially more interesting but mostly the colour is too pale.

\subsection{Mafic rocks}

The composition of the mafic rocks in the Kuru batholith varies from gabbro and diorite to quartz gabbro, quartz diorite (main rock type for black natural stone), and hornblende gabbro (collectively shown as gabbro/diorites in Fig. 1). The mafic rocks are usually massive and even-grained but sometimes heterogeneous with grain sizes from fine to coarse. Mafic constituents mingle with granites (Fig. 4), most frequently with the surrounding red granites. The main minerals of the quartz diorite are plagioclase, hornblende, biotite, and quartz (occasionally bluish) (Nyman, 2007). Biotite can often be seen as xenocrysts, giving the rock a spotted black appearance (Fig. 2C). Mafic, fine-grained, mostly rounded and mingled enclaves are found in the quartz diorite. Occasional aplite veins are observed.

Different kinds of mafic rock are quarried for domestic use (tombstones) in different parts of a quartz diorite quarry. Kuru Black (Fig. 2C) is a homogeneous black variety while Black Star (Fig. $2 \mathrm{D})$ is a special variety, containing white quartz rich inclusions and veins (1-3 cm in thickness). The spacing of the horizontal fracturing in the quartz diorite is $0.5-1.5 \mathrm{~m}$, and the sheeting is not as well- 
developed as in the grey granite. Vertical fractures are non-systematic and abundant with a spacing of $0.5-2 \mathrm{~m}$.

Additional future prospects in the mafic rocks have been identified (Härmä et al., 2006). The quality of the rocks suffers from the dense fracturing and the various light-coloured granitic veins and stripes.

\section{Geological structure of the Kuru granite batholith}

The southern parts of the CFGC are characterized by regional, tens of kilometres long, NW-SE trending lineaments (Selonen \& Ehlers, 1996; Nironen et al., 2000; Nironen, 2003). A second set of lineaments have a SW-NE strike (Nironen, 2003).
The three main directions of fractures in the Kuru batholith, measured in the field are $20^{\circ}, 60^{\circ}$ and $160^{\circ}$ of which the second one is most abundant (Nyman, 2007). The directions correlate well with those of the regional lineaments. A weak steeplydipping, mainly E-W striking foliation and an occasional steep lineation is observed in the granitic rocks of the batholith. The weak foliation is apparently overprinting and unrelated to the magmatic layering in the batholith.

The rocks of the Kuru batholith are exposed around the topographic depression of Lake Vankavesi (an intersection between the SW-NE and the NW-SE trending topographic fracture zones). The contacts between the different intrusive rocks have a rough correlation with the contour lines of the local topography indicating a gentle dip. The

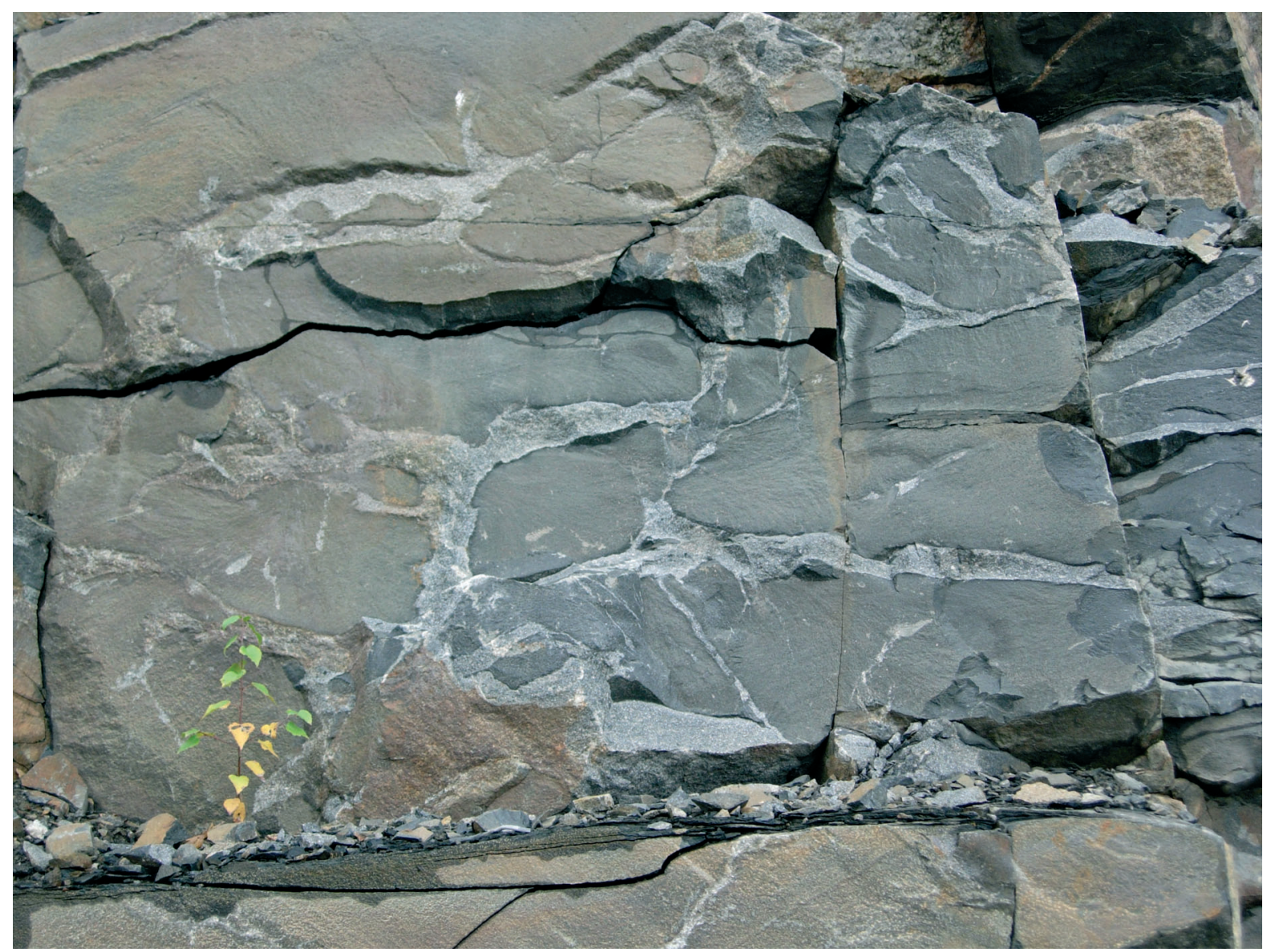

Fig. 4. Mingling (net-veining) between quartz diorite and granite in the Kuru granite batholith. Height of the little tree in the lower left corner is $50 \mathrm{~cm}$. 
grey granite covers the lower levels of the Vankavesi depression, around the shore of the lake, while the gabbros occupy the higher topography. The red granites form a 20-30 metres thick layer between grey granite underneath and the gabbros higher up. Two mapped areas of topography are shown in Fig. 5. The maps corroborate our general observations in the field (e.g. from the area in Fig. 5B) that the Kuru batholith is composed of roughly subhorizontal sheets of intrusion. The frequent mingling between mafic and granitic rocks indicates successions of intrusions of contrasting composition building up a layered series of intrusions.

Vertical drill holes in some of the quarries in the grey granite show red granites a few tens of metres deeper down, perhaps indicating a contact zone towards more mafic intrusions below - a positive magnetic anomaly over the deepest part of Lake Vankavesi (Nyman, 2007) also indicates that this could be the case.

\section{Discussion and summary}

The late synkinematic and postkinematic granitic intrusions along the southern side of CFGC have intrusion ages between approx. $1880 \mathrm{Ma}$ and 1870 $\mathrm{Ma}$ and are conceivably exposed at different levels in the crust at the present surface. The bimodal Kuru batholith (1875 $\pm 5 \mathrm{Ma}$; Nironen, 2003) exposes a laccolitic intrusion in contrast to the diapiric Orivesi and Juupajoki intrusions near by (Fig. 1, inset) (Selonen \& Ehlers, 1996). These intrusions are spatially in close connection to major lineaments, implying a phase of extensional tectonic situation, and tectonic control for the intrusions as indicated, e.g. by Selonen and Ehlers (1996) and Nironen et al. (2000). In the late synkinematic and postkinematic intrusions the general density of fractures is low (Selonen, 1994; Härmä et al., 2006) due to an absence of major subsequent deformations, enabling quarrying of large block sizes as required by the processing industry. Hence, regionally, the late synkinematic Kuru batholith is a location with high potential for natural stone.

As indicated by the description of the natural stone properties of the rock types, in the Kuru batholith all of the magmatic phases have a potential as commercially viable natural stone. However, the deposits are concentrated to the grey granite (Kuru Grey) in the middle (lower parts) of the exposed batholith. The rock is sound, even-grained, and homogeneous - especially suitable for quarrying. The well-developed sheeting is a feature that sets the grey granite apart from the other rock types in the batholith. This could be a result of the high grade of homogeneity and brittleness of the granite as compared to the other rock types (cf. Martell, 2006). Pressure release through melting of the thick overburden of the Pleistocene ice-sheet may also have contributed to the development of the sheeting. While the well-developed sheeting is beneficial for quarrying, the intense rock stress, especially in the deeper parts of the quarries poses a challenge. However, with proper quarry planning and preventive measures (e.g. slot drilling perpendicular to the maximum stress direction), the effects of the rock stress can be managed (Mononen, 2005).

The poor horizontal fracturing of the red granite (Kuru Redbrown) reduces the size of the quarried blocks, but the intense red brown colour gives the stone a good market value even as small blocks. The quartz diorite (Kuru Black) has densest fracturing of the quarried rock types in the Kuru batholith. However, the black colour is always highly valued in the market, and the "spotted" appearance with occasional blue quartz grains increase the commercial interest of the stone. Black Star is a unique product of the quartz diorite with the commercial potential solely based on the exciting appearance. The popularity of these stones underlines the importance of a commercially appealing appearance of the product in the natural stone trading (cf. Selonen et al., 2011).

Our observations on the Kuru batholith indicates a "stratigraphical" succession of gently dipping intrusions with a middle level of grey granite followed upwards by a thin mingled zone of red granites and by gabbros and diorites on top. Vertical drill holes through the grey granite and a positive magnetic anomaly over the lowest part of Lake Vankavesi allow us to speculate that similar successions of rocks could be found underneath. 

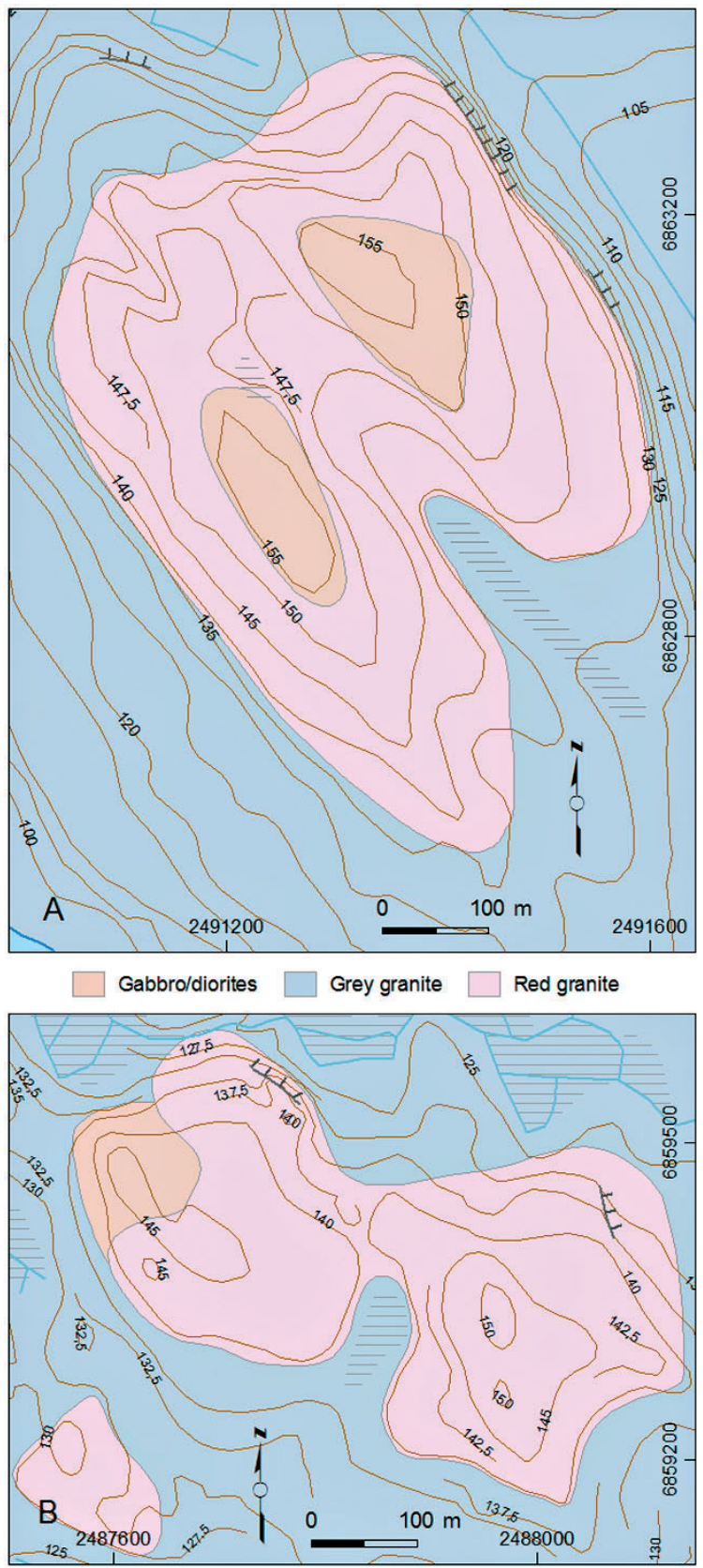

Basemaps: @ National Land Survey of Finland, licence no 13/M ML/12
The large topographical depression around Lake Vankavesi in the middle of the batholith exposes today the subhorizontal layer of the grey granite with good natural stone properties. The lake represents an intersection between the SW-NE and the NWSE trending fracture zones and a weakness in the bedrock, prone to glacial abrasion clearly observed in the NW-SE orientation of the water courses and topography of the area. The well-developed sheeting of the grey granite, parallel to the peneplane together with NW-SE fracture zones, can have also contributed to the formation of the depression during the ice movements from NW to SE. The fact that the grey granite is exposed in the Vankavesi depression was also of great importance for the beginning of stone industry in the area because of easy access to the granite and good water transport facilities.

The localization of the natural stone deposits in the Kuru granite batholith is geologically controlled by the subhorizontal structure of the laccolitic batholith, exposing layers of rocks with potential for natural stone (e.g. large areas of grey granite) subparallel to the present level of erosion. The results of this study are in accordance with our previous observations on the significance of the structural position of intrusions as one of the geological constraints localizing the deposits (e.g. Selonen et al. 2011).

\section{Acknowledgements}

Prof. Raimo Uusinoka and Dr. Mikko Nironen critically reviewed the manuscript which is gratefully acknowledged. Ms. Mirjam Ajlani (Geological Survey of Finland, GTK) is thanked for preparing the maps. All photos are taken by the authors. The image scanning of rock samples in Fig. 2 was carried out

Fig. 5. Lithologies and topographical contours in two selected areas in the Kuru granite batholith. A. The topographically lowest parts of the area in the northern part of the batholith consist of weakly foliated, medium to even-grained, homogeneous grey granite with occasional dark enclaves. Higher up in topography the rock changes into red coloured granite. The red granite has a slightly coarser grain-size (potassium feldspar $\sim 0.3-0.5 \mathrm{~cm}$ ). On the top of the outcrop the rock is dioritic, containing numerous veins of red granite, forming a coarse breccia. The diorite is even-grained and has a dark grey colour. B. In the middle of the batholith the area covered by red granite increases westwards and towards topographically higher ground. The amount of quartz diorite increases, first as large enclaves, net-veining, or flame-like schlieren in the red granite and further west as the dominating constituent containing white, medium to coarse-grained granitic veins. The topographically highest parts of the outcrops to the northwest (see Fig. 1) consist of quartz diorites, containing fine-grained mafic enclaves and granite veins. See Fig. 1 for locations. 
in the GTK image processing laboratory by Mr. Hannu Luodes. The natural stone prospecting in the Kuru district was carried out as a part of a regional exploration project completed by the GTK. It was financed by an EU fund (The Regional Rural Development Programme of Finland 2000-2006, ALMA), private companies, local municipalities, and the GTK.

\section{References}

Aurola, E. 1967. Building stones of Kuru, Finland. Geological Survey of Finland. Geotechnical publications $\mathrm{Nr} 71,64$ pp. (in Finnish with English summary).

Härmä, P., Karttunen, K., Nurmi, H., Nyholm, T., Sipilä, P. \& Vuokko, J. 2006. Natural stone exploration project in the Tampere region 2001-2005. Geological Survey of Finland, Report KA 33/2006/1. 24 pp. +8 app. (in Finnish with English summary).

Kylkilahti, P. 1989. Näsijärven seudun kiviteollisuus 1800-luvun jälkipuoliskolta 1980-luvulle. MSc thesis, University of Jyväskylä, Department of Finnish history, Jyväskylä, Finland. (in Finnish).

Martel, S. 2006. Effect of topographic curvature on near-surface stresses and application to sheeting joints. Geophysical Research Letters 33, 101308.

Matisto, A. 1961. Geological map of Finland 1:100 000. Explanation to the map of rocks, sheet 2213 Kuru. Geological Survey of Finland. 40 pp. (in Finnish with English summary).

Mononen, S. 2005. The influence of rock stress on dimension stone quarrying. Licentiate thesis. Helsinki University of Technology. Department of civil and environmental engineering. Espoo, Finland. (in Finnish with English summary).

Nironen, M. 2003. Central Finland Granitoid Complex Explanation to a map. Geological Survey of Finland,
Report of Investigation 157, 1-45. (in Finnish with English summary).

Nironen, M. 2005. Proterozoic orogenic granitoid rocks. In: Lehtinen, M., Nurmi, P.A. \& Rämö, O.T. (eds.) Precambrian Geology of Finland - Key to the Evolution of the Fennoscandian Shield. Elsevier B.V. Amsterdam, Netherlands, pp. 443-480.

Nironen, M., Elliott, B. A. \& Rämö, O. T. 2000. 1.88-1.87 Ga postkinematic intrusions of the Central Finland Granitoid Complex: a shift from C-type to A-type magmatism during lithospheric convergence. Lithos 53, 37-58.

Nyman, R. 2007. Geological, geophysical, and structural features of the Kuru batholith. MSc thesis, Åbo Akademi University, Department of geology and mineralogy, Tur$\mathrm{ku}$, Finland.

Selonen, O. 1994. K.H. Renlundin säätiön rakennuskivitutkimukset 1982-1993. K.H. Renlund Foundation. Tur$\mathrm{ku}$, Finland. (in Finnish). 43 p.

Selonen, O. \& Ehlers, C. 1996. The Orivesi Granite Batholith, Southern Central Finland - Characteristics and Emplacement. Bulletin of the Geological Society of Finland 68, 11-24.

Selonen, O. \& Härmä, P. 2003. Stone resources and distribution: Finland. In: Selonen, O. \& Suominen, V. (eds.) Nordic Stone. Geological Science series, UNESCO publishing, Paris, France, 19-29.

Selonen, O., Ehlers, C., Luodes, H. \& Karell, F. 2011. Magmatic constraints on localization of natural stone deposits in the Vehmaa rapakivi granite batholith, southwestern Finland. Bulletin of the Geological Society of Finland 83, 25-39.

Simonen, A. 1952. Geological map of Finland 1:100 000. Explanation to the map of rocks, sheet 2124 ViljakkalaTeisko. Geological Survey of Finland. 64 pp. (in Finnish with English summary). 